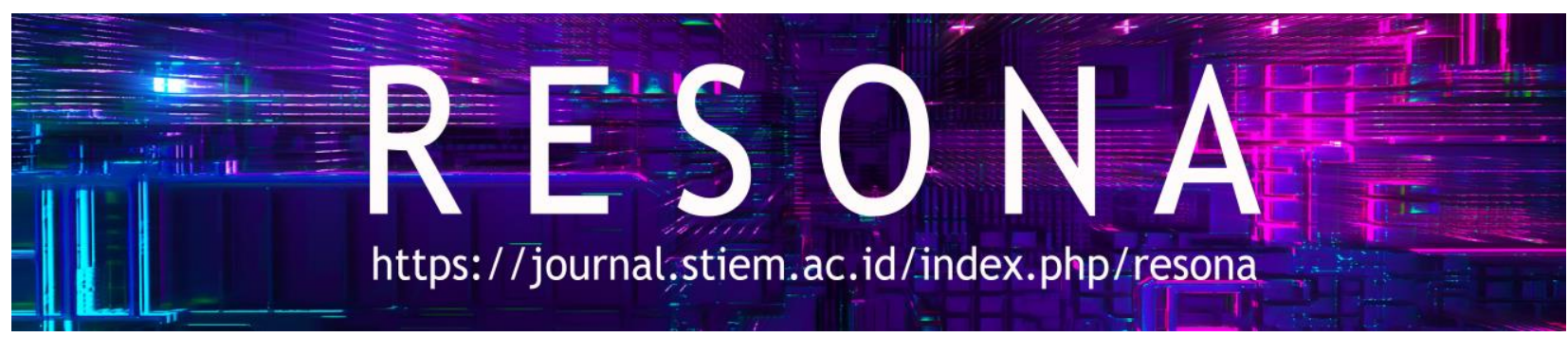

Teknik Penggunaan Pupuk Fosfat Terhadap Rumput Laut (Gracilaria verrucosa) Di Tambak Budidaya Lakawali Kabupaten Luwu Timur Sulawesi Selatan

Irman Halid $^{1}$, Patahiruddin ${ }^{2}$

${ }^{1,2}$ Universitas Andi Djemma

\section{INFO NASKAH}

Diserahkan

14 Oktober 2019 Diterima

17 Oktober 2019

Diterima dan Disetujui 31

Desember 2019

Kata Kunci:

Fosfat, Gracillaria Verrucosa,

Tambak, Budidaya

Key Words:

Phosphate,

Gracillaria Verrucosa, Pond, Aquaculture

\section{ABSTRAK}

Fosfat merupakan salah satu nutrien yang mempengaruhi pertumbuhan dan menjadi unsur hara yang esensial bagi tumbuhan dan algae akuatik serta sangat mempengaruhi tingkat produktivitas perairan. Rumput laut (Gracilaria verrucosa) merupakan salah satu jenis alga merah (Rhodophyta) yang banyak dibudidayakan di tambak dan menjadi bahan dasar penghasil agar. Agar digunakan sebagai pengental yang larut dalam air dan pengemulsi dalam industri makanan, obat-obatan, kosmetik, kertas, tekstil, minyak bumi, dan bioteknologi. Tingginya permintaan, harga tinggi, bibit mudah diperoleh dan masa panen yang singkat menjadikan G.verrucosa sebagai salah satu komoditas unggulan di sektor budidaya perikanan. Pengabdian ini menggunakan metode penyuluhan yang dilaksanakan pada tanggal 30 Pebruari 2019 dengan tujuan untuk memperkenalkan teknologi budidaya $G$.verrucosa yang efektif dan efisien. Dengan kegiatan pegabdian, diharapkan terjadi peningkatan partisipasi pembudidaya G.verrucosa yang bertujuan untuk memfasilitasi masyarakat (sasaran) dalam menerapkan strategi produksi agar mempercepat terjadinya perubahan-perubahan kondisi sosial, politik dan ekonomi sehingga mereka dapat (dalam jangka panjang) meningkatkan taraf hidup pribadi dan masyarakat pembudidaya G.verrucosa di Lakawali, Kabupaten Luwu Timur, Sulawesi Selatan. Dampak dan manfaat kegiatan ini adalah peningkatan pengetahuan penggunaan pupuk fosfat, keterampilan dan sikap pembudiya G.verrucosa. Capaian keberhasilan kegiatan penyuluhan ditandai timbulnya partisipasi aktif dari pembudidaya G.verrucosa dalam mengadopsi teknologi dan peningkatan produksi G.verrucosa.

Abstract. Phosphate is one of the nutrients that affect growth and is an essential nutrient for plants and aquatic algae and dramatically affects the level of marine productivity. Seaweed (Gracilaria verrucosa) is one type of red algae (Rhodophyta), which is widely cultivated in ponds and is the essential ingredient in producing agar. Agar used as a water-soluble thickener and emulsifier in the food, medicine, cosmetics, paper, textile, petroleum, and biotechnology industries. High demand, high prices, easy to obtain seeds, and a short harvest period make G.verrucosa as one of the leading commodities in the aquaculture sector. This service uses counseling methods implemented on 30 February 2019 to introduce effective and efficient G.verrucosa cultivation technology. Hopefully, the community service activities will increase in the participation of G.verrucosa farmers who aim to facilitate the community (target) in implementing production strategies to accelerate changes in social, political, and economic conditions so that they can (in the long term) improve their personal and community lives. G.verrucosa farmers in Lakawali, East Luwu Regency, South Sulawesi. The impact and benefits of this activity are increased knowledge of the use of phosphate fertilizer, the skills, and attitudes of G.verrucosa pembudiya. The achievement of the success of extension activities marked the emergence of active participation of G.verrucosa farmers in adopting technology and increasing G.verrucosa production. 


\section{Pendahuluan}

Budidaya rumput laut (Gracilaria verrucosa) memiliki peranan penting dalam usaha meningkatkan produksi perikanan untuk memenuhi kebutuhan pangan dan gizi serta memenuhi kebutuhan pasar dalam negeri dan luar negeri, memperluas lapangan pekerjaan, meningkatkan pendapatan dan kesejahteraan nelayan dan petani ikan serta menjaga kelestarian sumber hayati perairan (Aslan, 2006). Budidaya G.verrucosa merupakan kegiatan budidaya yang paling populer karena G.verrucosa mampu beradaptasi terhadap berbagai kondisi ekologi di tambak, tingkat produksi yang lebih tinggi, dan kualitas gel yang lebih baik (Alifatri, 2012).

Tingginya permintaan komoditas rumput laut untuk kebutuhan industri di dalam dan luar negeri, maka harus diimbangi dengan upaya penyediaan bahan baku yang berkualitas dan berkesinambungan (Rejeki dkk., 2018). Produksi G.verrucosa dari tambak dapat mencapai minimal satu ton kering/ha/periode tanam (4-6 minggu) (Alamsjah dkk., 2009). Salah satu kendala utama dalam pencapaian jumlah produksi adalah kondisi nutrient substrat dan nutrient perairan tambak. Fosfat merupakan unsur yang esensial bagi tumbuhan dan algae aquatik serta sangat mempengaruhi tingkat produktivitas perairan (Yunus dkk., 2010). Adanya pertumbuhan G.verrucosa yang berbeda pada tiap lokasi tambak dengan metode budidaya yang sama, menjadi alasan untuk melakukan suatu kegiatan pengabdian di Desa Lakawali, Kabupaten Luwu Timur, Provinsi Sulawesi Selatan.

Mendasari hal tersebut, maka diperlukan suatu penyuluhan dan pendampingan. Penyuluhan dan pendampingan khususnya mengenai teknik penggunaan pupuk fosfat di tambak budidaya guna memberikan pertumbuhan G.verrucosa yang lebih baik pada masing-masing tambak budidaya sehingga disetiap tambak budidaya dapat diperoleh pertumbuhan G.verrucosa yang baik. Harapan lainnya yaitu diperoleh hasil produksi yang optimal dalam upaya mewujudkan target produksi rumput laut nasional sehingga kebutuhan pasar dunia terhadap rumput laut dari Indonesia dapat terpenuhi. Pada akhirnya akan meningkatan pendapatan petani di Desa Lakawali, Kabupaten Luwu Timur, Provinsi Sulawesi Selatan.

\section{Masalah}

Kegiatan budidaya di Desa Lakawali, Kabupaten Luwu Timur, Provinsi Sulawesi Selatan sering mengalami masalah kegagalan. Salah satu penyebab masalah kegagalan tersebut adalah thallus yang sering mengalami keputihan atau biasa disebut penyakit ice-ice. Penyakit tersebut dapat dicegah dan dihentikan dengan penggunaan pupuk fosfat yang tepat dosis dan tepat cara. Untuk mengatasi hal tersebut diperlukan beberapa solusi antara lain: identifikasi lokasi budidaya G.verrucosa yang menjadi target pelaksanaan penyuluhan, melakukan 
bimbingan dan bantuan teknis penggunaan pupuk fosfat pada kegiatan budidaya G.verrucosa dan melaksanakan tugas pendampingan dan evaluasi penggunaan pupuk fosfat pada kegiatan budidaya G.verrucosa sebagai hasil dari kegiatan penyuluhan.

\section{Metode}

Penyuluhan dilaksanakan di Desa Lakawali Kabupaten Luwu Timur Provinsi Sulawesi Selatan pada tanggal 25 Februari 2019 (Gambar 1). Kegiatan penyuluhan yang dilakukan meliputi 3 (tiga) tahapan, yaitu: 1) Identifikasi lokasi budidaya G.verrucosa yang menjadi target pelaksanaan penyuluhan; 2) Melakukan bimbingan dan bantuan teknis penggunaan pupuk fosfat pada kegiatan budidaya G.verrucosa; dan 3) Melaksanakan tugas pendampingan dan evaluasi penggunaan pupuk fosfat pada kegiatan budidaya G.verrucosa sebagai hasil dari kegiatan penyuluhan.

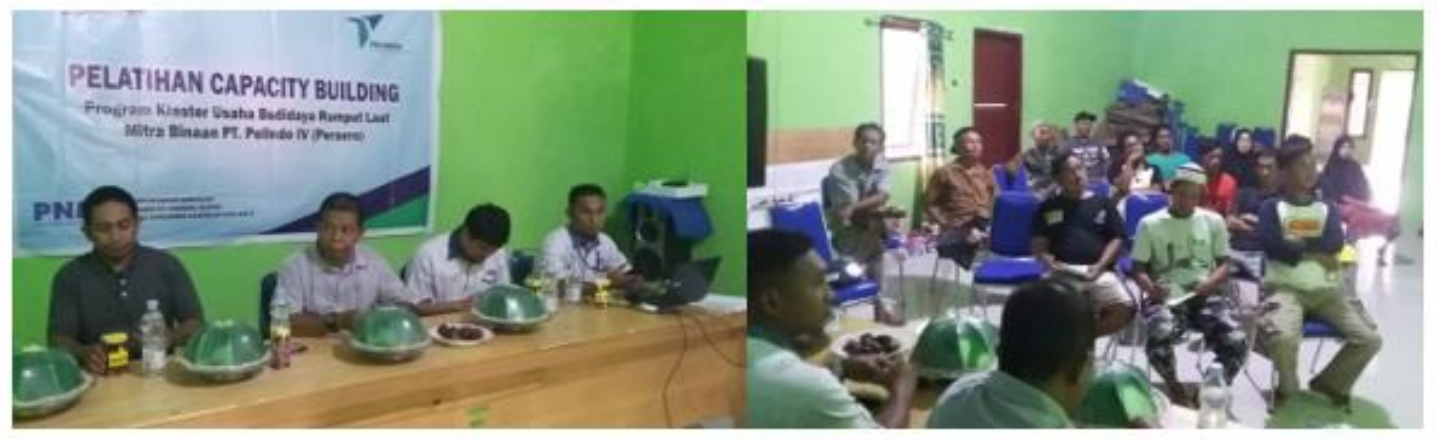

Gambar 1. Penyuluhan aplikasi pupuk fosfat pada budidaya G.verrucosa

Keberhasilan penyuluhan aplikasi pupuk fosfat pada budidaya G.verrucosa dapat tercapai apabila dilakukan persiapan yang matang melalui tahap perencanaan hingga tahap evaluasi. Perencanaan perlu dilakukan terutama pada lokasi budidaya G.verrucosa yang pertumbuhannya kurang bagus. Hal tersebut dilakukan demi suksesnya pelaksanaan kegiatan penyuluhan teknik penggunaan pupuk phosfat, sedangkan evaluasi diperlukan sebagai bahan pertimbangan dalam perbaikan hal-hal yang dirasa masih kurang dalam penyelenggaraan penyuluhan. Semua hal tersebut akan tercakup dalam proses penyelenggaraan kegiatan penyuluhan teknik penggunaan pupuk fosfat pada budidaya G.verrucosa.

\section{Hasil dan Pembahasan}

Kegiatan penyuluhan tentang teknik aplikasi fosfat di tambak budidaya di Lakawali Kabupaten Luwu Timur dilaksanakan langsung di tambak budidaya G.verrucosa. Tambak di lokasi tersebut termasuk dalam kategori tambak tradisional. Salah satu ciri tambak tradisional yaitu pergantian air dilakukan dengan mengandalkan pasang surut air laut. Batas antara laut 
dengan kawasan pertambakan di Desa Lakawali yaitu hutan mangrove. Persedian sumber air tawar di kawasan tersebut cukup tersedia karena kawasan tambak berada di sekitar muara sungai besar yang hulunya dari Danau Towuti.

Penyuluhan di Desa Lakawali dilaksanakan karena kegiatan budidaya di daerah tersebut sering mengalami kegagalan. Salah satu penyebab kegagalan tersebut adalah thallus yang sering mengalami keputihan atau biasa disebut penyakit ice-ice. Penyakit tersebut dapat dicegah dan dihentikan dengan penggunaan pupuk fosfat yang tepat dosis dan tepat cara. Teknik budidaya G.verrucosa di Kabupaten Luwu Timur, memiliki kesamaan dengan beberapa daerah lain terutama dalam penggunaan pupuk anorganik. Akan tetapi, perlu diperhatikan bahwa penggunaan pupuk anorganik yang berlebihan atau tidak tepat dosis dapat membahayakan lingkungan dan G.verrucosa yang dibudidayakan. Perairan Desa Lakawali Kabupaten Luwu Timur berada di kawasan Teluk Bone. Kawasan Teluk Bone yang berlokasi di Kabupaten Luwu Timur, memiliki tanah yang bersifat sulfat masam (DKP Sul-Sel, 2008) dan kadar fosfat di perairan sangat rendah (Patahiruddin, 2015). Dengan kondisi tersebut, maka perlu metode dan teknik baru budidaya G.verrucosa di Kabupaten Luwu Timur jika ingin berhasil kegiatan budidayanya. Teknik aplikasi pupuk fosfat merupakan cara yang tepat untuk dilakukan di daerah tersebut yaitu dengan melarutkan pupuk fosfat pada saat diaplikasikan. Adanya anggapan bahwa pertumbuhan yang kurang bagus diawal penebaran disebabkan oleh kualitas bibit G.verrucosa yang kurang baik. Padahal rendahnya laju pertumbuhan G.verrucosa di tambak area penyuluhan terutama pada awal pemeliharaan disebabkan G.verrucosa masih melakukan proses adaptasi terhadap kondisi lingkungan tambak budidaya. Faktor lingkungan merupakan salah satu faktor yang mempengaruhi pertumbuhan dan kehidupan G.verrucosa (Anggadiredja, 2006).

Penyebab lain rendahnya pertumbuhan G.verrucosa di tambak budidaya di Lakawali, yaitu rendahnya pH pada substrat. Menurut Soesono (1989) dalam Alifatri (2012), pengaruh pH bagi pertumbuhan G.verrucosa sangat besar dan penting karena kisaran $\mathrm{pH}$ yang kurang dari 6,5 akan menekan laju pertumbuhan bahkan tingkat keasamannya dapat mematikan dan tidak ada laju reproduksi. Pada $\mathrm{pH}$ yang rendah juga, kadar phosfat tidak dapat dimanfaatkan dengan baik karena terikat oleh ion Fe dan Al. Pemberian kapur sebelum melakukan kegiatan budidaya perlu dilakukan guna menurunkan keasaman tanah dengan menaikkan derajat $\mathrm{pH}$ tanah. Menurut Zatnika (2009), hampir seluruh alga mempunyai kisaran daya penyesuaian terhadap $\mathrm{pH}$ antara 69. Dilokasi penyuluhan, pembudidaya dalam hal ini petani tidak pernah melakukan pemberian kapur. Dosis kapur yang disarankan adalah satu ton/ha untuk menaikan satu derajat $\mathrm{pH}$. 
Pertumbuhan bagus pada area budidaya di lokasi penyuluhan hanya terjadi di pada musim-musim tertentu saja dan jika diamati dengan baik maka persentase pertumbuhan harian hanya terjadi diakhir pemeliharaan. Hal tersebut terjadi karena persediaan hara yang tinggi pada substrat. Pertumbuhan G.verrucosa, ditandai dengan peningkatan kerapatan G.verrucosa diakhir pemeliharaan akan dipengaruhi oleh laju sintasan dan reproduksi. Brower et al (1990) menjelaskan bahwa populasi organisme baik hewan maupun tumbuhan proporsi individu yang muda dan tua selalu berubah dalam unit waktu tertentu. Sementara itu, perubahan musim yang terjadi akan mempengaruhi kondisi substrat perairan, suhu, arus, salinitas, kecerahan air, hama dan penyakit (Anggadiredja, 2006). Kuat dugaan bahwa pertumbuhan G.verrucosa pada musim tanam tertentu mengalami pertumbuhan cukup tinggi dikarenakan G.verrucosa menyerap nutrien berupa fosfat dan nitrat cukup tinggi pada musim tersebut. Hasil penelitian Gordillo et al. (2002) menunjukkan bahwa laju penyerapan fosfat dan nirat berkesesuaian dan memiliki korelasi positif dengan peningkatan laju pertumbuhan G.verrucosa. Pertumbuhan dan biomassa dapat tercapai dengan baik bila G.verrucosa tercukupi oleh kedua unsur tersebut (Buschmann et al., 2004. Hasil penelitian (Patahiruddin, 2015) menujukkan bahwa laju penyerapan nutrient di substrat cukup tinggi terjadi pada akhir pemeliharaan.

Kerapatan bibit atau padat penebaran bibit yang dilakukan pembudidaya di Lakawali berkisar antara 2-3 ton/ha atau 200-300gr/ $\mathrm{m}^{2}$. Hal tersebut dilakukan dengan alasan agar cepat panen apabila kondisi musim lagi baik. Padahal pertumbuhan G.verrucosa disuatu daerah harus disesuaikan degan daya dukung lingkungan karena kerapatan biomassa akan mencapai maksimum ketika biomassa G.verrucosa sama dengan carrying capacity, sehingga pada saat itu G.verrucosa tidak lagi melakukan pertumbuhan (Kartono dkk., 2008). Kerapatan bibit awal merupakan salah satu masalah yang terselesaikan dengan adanya kegiatan penyuluhan aplikasi pengguanaan pupuk phosfat pada budidaya G.verrucosa. Hasil penelitian budidaya G.verrucosa di Kabupaten Luwu menunjukkan bahwa kerapatan bibit $150 \mathrm{gr} / \mathrm{m}^{2}$ memberikan total rerata laju pertumbuhan harian yang lebih baik (Patahiruddin, 2015).

Kualitas air berupa salinitas, suhu dan oksigen terlarut di lokasi penyuluhan di Lakawali sebagai berikut, yaitu: salinitas berada pada kisaran 27- $30 \mathrm{ppm}$, hal ini sesuai pendapat Alamsjah., (2010) menyatakan bahwa salinitas yang baik untuk pertumbuhan G.verrucosa berkisar antara 23 - 30 ppm dan yang optimum adalah berkisar antara 27-30 ppm. Suhu tambak budidaya di di Lakawali, yaitu $32-34^{\circ} \mathrm{C}$. Suhu tersebut cukup tinggi tetapi masih layak untuk pertumbuhan G.verrucosa. Menurut Afrianto dan Liviawaty (1993) dalam Alifatri (2012), rumput laut tumbuh dan berkembang dengan baik pada perairan yang memiliki kisaran suhu 26- 
$33{ }^{\circ} \mathrm{C}$. Oksigen terlarut (DO) berasal dari difusi udara dan hasil fotosintesis organisme berklorofil yang hidup dalam suatu perairan dan dibutuhkan oleh organisme untuk mengoksidasi zat hara yang masuk ke dalam tubuhnya (Nybakken, 1988). Hasil pengukuran DO berada dikisaran, yaitu 3,25-4,56 ppm. Tijssen et al. (1990) menyatakan bahwa kadar oksigen terlarut semakin rendah dengan bertambahnya kedalaman dan meningkatnya suhu perairan.

Pertumbuhan G.verrucosa di di Lakawali lebih banyak disebabkan oleh faktor ekologis tambak budidaya terutama nutrient di substrat. Hasil penelitian (Patahiruddin, 2015) menunjukkan bahwa kandungan kadar nitrat dan phosfat di substrat tambak budidaya mengalami penurunan konsentrasi setiap waktu. Hasil pengukuran kadar phosfat air yang tidak terdeteksi menyebabkan teknik budidaya yang dilakukan, harus berbeda dengan daerah lain. Berdasarkan hal tersebut, maka teknik budidaya G.verrucosa di di Lakawali harus menggunakan fosfat dengan cara aplikasi dilarutkan terlebih dahulu sehingga berbeda dengan budidaya G.verrucosa pada umumnya. Menurut Glenn and Doty (1990), selain suhu, tingkat penyinaran, dan derajat pergerakan air yang tinggi, produktivitas G.verrucosa secara langsung sangat tergantung pada ketersediaan nutrien perairan. Laju penyerapan nutrien rumput laut bervariasi tidak hanya antar spesies tetapi juga antara lokasi dimana rumput laut tersebut hidup (Tomokazu et al., 2004). Evaluasi hasil penyuluhan menunjukkan bahwa rerata laju pertumbuhan G.verrucosa di Desa Lakawali yaitu 3\%/hari setelah aplikasi penggunaan pupuk phosfat. Hal tersebut membuktikan bahwa kegiatan penyuluhan berhasil.

\section{Simpulan dan Saran}

Pemberian penyuluhan teknik penggunaan pupuk phosfat pada budidaya G.verrucosa di Kabupaten Luwu Timur penting dilakukan karena adanya kondisi ekologis yang berbeda dengan daerah lain, sementara pengetahuan pembudidaya (petani) secara umum sama antara daerah yang satu dengan daerah yang lainnya. Kondisi ekologis tambak yang memberikan memberikan pengaruh terhadap pertumbuhan G.verrucosa adalah phosfat dan $\mathrm{pH}$ di substrat. Pemberian penyuluhan dan pendampingan yang tepat akan memberikan manfaat pada peningkatan pengetahuan, keterampilan dan sikap pembudidaya G.verrucosa dengan aktif berpartisipasi dalam mengadopsi teknologi penggunaan puuk pada budidaya G.verrucosa

\section{Ucapan Terima Kasih}

Kegiatan ini terlaksana dengan baik karena dukungan dari berbagai pihak. Oleh karena itu kami mengucapkan terima kasih kepada pemrakarsa kegiatan yaitu PT. Permodalan Nasional 
Madani (PNM) Cabang Palopo melalui program pelatihan capacity building program klaster usaha budidaya rumput laut mitra binaan PT. Pelindo IV (Persero). Demikian pula dengan kelompok pembudidaya rumput laut Desa Lakawali atas partisipasinya pada kegiatan ini.

\section{Daftar Pustaka}

Alamsjah, M.A., N.O Ayuningtiaz., dan S. Subekti. 2010. Pengaruh lama penyinaran terhadap pertumbuhan dan klorofil a Gracilaria verrucosa pada sistem budidaya indoor. Jurnal Ilmiah Perikanan dan Kelautan Vol. 2 No. 1: 21-30.

Alifatri, L. 2012. Laju pertumbuhan dan kandungan agar Gracilaria verrucosa dengan perlakuan bobot bibit terhadap jarak tanam di tambak balai layanan usaha produksi perikanan budidaya Karawang. Jawa Barat. Skripsi. IPB. Bogor.

Anggadiredja, J.T., Zatnika, A., Purwoto, H., dan Istini, S. 2006. Rumput laut; pembudidayaan, pengolahan dan pemasaran komoditas perikanan potensial. Penebar Swadaya. Jakarta.

Aslan, M. 2006. Budidaya rumput laut. Kanisius. Yogyakarta.

Brower, J.E., Zar, J.H., and von Ende, C.N. 1990. Field and laboratory methods for general ecology. Third edition. America: Wm.C. Brown Publishers.

Buschmann, A.H., D. Varela., M. Cifuentes., M.C. Hernandez-Gonzalez., L. Henriquez.,R. Westermeier., and J.A. Correa. 2004. Experimental indoor cultivation of the carrageenophytic red algae Gigartina skottsbergii. Aquaculture 241: 357-370.

Dinas Kelautan dan Perikan Sulawesi Selatan, 2008. Faktor pengelolaan yang berpengaruh terhadap produksi rumput laut (Gracilaria verrucosa) dl tambak tanah sulfat masam (studi kasus dl Kabupaten Luwu, Provinsi Sulawesi Selatan. http://ikanmania.wordpress.com. Di akses tanggal 20 November 2016.

Glenn, E.P., and M.S. Doty. 1990. Growth of seaweed Kappaphycus alvarezii, Kappaphycus striatum and Eucheuma denticulatum as effeted by enviroment in Hawaii. Aquaculture 84: 245-255.

Gordillo, F.J.L., M.J. Dring., and G. Savidge. 2002. Nitrate and phosphate uptake characteristics of three species of brown algae cultured at low salinity. Marine Ecology Progress Series Vol. 234: 111-118.

Kartono., M.Izzati., Sutimin., dan D. Insani. 2008. Analisis model dinamik pertumbuhan biomassa rumput laut Gracillaria verrucosa. Jurnal Matematika Vol. 11 No.1: 20-24.

Nybakken, J.W. 1988. Biologi laut, suatu pendekatan ekologi. Terjemahan. Gramedia Jakarta. 459 hal.

Patahiruddin. 2015. Pengaruh kerapatan bibit terhadap pertumbuhan rumput laut (Gracilaria verrucosa (Hudson) Papenfuss) di tambak budidaya Kabupaten Luwu Sulawesi Selatan. Tesis. 
Rejeki, S., R.W.Ariyati,. L.L. Widowati., and R.H. Bosma. 2018. The effect of three cultivation methods and two seedling types on growth, agar content and gel strength of Gracilaria verrucosa. Egyptian Journal of Aquatic Research 44. 65-70.

Tijssen, S.B., M. Mulder and F.J. Wetsteyn. 1990. Production and Consumption Rates of Oxygen, and Vertical Oxygen Structure in the upper $300 \mathrm{~m}$ in the eastern Banda Sea During and After the Upwelling Season, August 1984 and February/ March 1985. -Proc. Snellius-II Symp., Neth. J. Sea Res. 25: 485 - 499.

Tomokazu, N., Y. Kosuke., D. Aki., and W. Yoso. 2004. Nitrate and phosphate uptake rates of Sargassum patens and Sargassum siliquastrum. Kyoto Furitsu Kaiyo Senta Kenkyu Hokoku, vol. 26. Japan. Page 21-29.

Yunus., I.W. Abida., dan F.F. Muhsoni. 2010. Pengaruh fosfat (TSP 36) terhadap pertumbuhan rumput laut. Jurnal Kelautan Vol 3. No 2.

Zatnika, A. 1994. Teknologi budidaya rumput laut. Makalah pada seminar pekan akuakultur V. Tim rumput laut Badan Pengkajian dan Penerapan Teknologi (BPPT). Jakarta. 